\title{
Trade Effect of the Free Trade Zone
}

\author{
Chao Zhou ${ }^{1}$, \& Ying $\mathrm{Su}^{2}$ \\ ${ }^{1}$ School of Central University of Finance and Economics, Beijing, China \\ ${ }^{2}$ Company of China Construction Bank (Beijing Branch), Beijing, China \\ Correspondence: Chao Zhou, School of Central University of Finance and Economics, Beijing, China.
}

Received: November 12, 2020

Accepted: December 11, 2020

Online Published: December 18, 2020

doi:10.5539/ibr.v14n1p34

URL: https://doi.org/10.5539/ibr.v14n1p34

\begin{abstract}
Facing to the increasingly complex international environment and the new normal of China's economic growth, the pilot of free trade zone is an important measure for China to further deepen reform and opening up. Promoting trade liberalization is an important part of the construction of the free trade zone. Based on the city panel data from 2004 to 2018, this paper analyzes the trade effects of 11 free trade zones established in 2017 and before by using the method of period by period did. Also the trade effect of each free trade zone is analyzed separately by the method of synthetic control. The results show that, firstly, the free trade zone has obvious trade promotion effect on total trade and export trade, but not on import trade. Second, the trade promotion effect of the pilot free trade zone is not significant in the eastern region, but there is an obvious trade promotion effect in the central and western regions. Thirdly, the analysis of each pilot free trade zone also shows some heterogeneity. Generally speaking, the trade effect of export is greater than that of import. Specifically speaking, the pilot free trade zone shows certain heterogeneity, which may be related to the local economic development level and econnmic scale.
\end{abstract}

Keywords: free trade zone; phased did; synthetic control; trade effect

\section{Introduction}

Since China's reform and opening up, the three major driving forces of economic growth are export, investment and consumption. The achievements of China's foreign trade development are obvious. China's total import and export volume has been on an obvious upward trend. However, with the further development of China's economy, we started talking about the "new normal" of economic growth, and the growth rate has slowed down. Especially after the U.S. subprime mortgage crisis, the developed capitalist countries attempted to speed up the reconstruction of international economic and trade rules, from emphasizing the pursuit of "free trade" to emphasizing the pursuit of "fair trade", and by restructuring the rules to adjust the global industrial chain layout. In order to further promote economic growth and better conform to international trade rules, China's pilot free trade zone has been rapidly promoted as a test field of reform and opening up. In September 2020, China has set up three new pilot free trade zones in Beijing, Hunan and Anhui. So far, China has established 21 pilot free trade zones. According to an official from the Ministry of Commerce, from January to may 2020, 18 pilot free trade zones across the country actually used 60.257 billion yuan of foreign investment, realizing $17 \%$ of foreign investment in $4 \%$ of the total land area ${ }^{1}$. This paper analyzes the import and export situation of the 11 early established free trade zones. According to statistics, by the end of 2018, the number of newly established foreign-funded enterprises, the actual use of foreign capital, and the proportion of total import and export in China increased by $15.54 \%, 12.12 \%$ and $12.25 \%$ respectively by the end of 2018 .However, whether the FTZs have led to the growth of local trade? What are the mechanisms of these FTZs driving the growth of trade? Are there any heterogeneity among the pilot free trade zones? These all need to be investigated, which is the focus of this paper.

\section{Literature Review and Typical Facts}

Free Trade Zone originated from the stipulation of "free zone" in the World Customs Organization (WCO) in 1973. The usual international free trade zone is developed from the free trade port and follows the management system of "first line liberalization, second line management and zone free ". The earliest free trade zone can be

\footnotetext{
${ }^{1}$ The corresponding figures come from China Business News.
} 
traced back to the ancient Greek times. At that time, the Phoenicians protected foreign merchant ships from any interference in the ports of Tyre and Carthage. In 1228, Marseille port in Southern France designated an exclusive zone in the port area, in which foreign goods could enter and leave freely without any tax. The world's first named after the free port is Italy in 1547 in the Gulf of Genoa to establish the free port of regogan. In the following 200 years, the free trade zones were mainly developed in Europe. At that time, the big trading countries established free ports one after another. Italy, Germany, France, Denmark, Portugal and other countries took advantage of their geographical location to attract foreign goods to this port by means of tariff-free, which made the free trade zone play a role of commodity distribution center ${ }^{2} \circ$ After the 1920 s, free trade zones began to appear in the American continent. In 1936, the United States established the first foreign trade zone in Brooklyn, New York. The early free trade zone's business activities were relatively single, mainly engaged in foreign trade and re export trade, and had relatively strict regulations on the business in the zone. After World War II, the free trade zone began to develop gradually, and the new situation of "export processing zone" as a free trade zone began to appear on the stage of history. According to the World's First Association Of Special Economic Zones(WEPZA), the earliest export processing zone is the free trade zone on Puerto Rico island from 1947 to 1951, while the Kaohsiung Export Processing Zone established in the 1960s in Taiwan China, is the first free trade zone officially named after "export processing zone". After the 1960s, various types of free trade zones began to appear in the world, mainly including free ports, free zones, foreign trade zones, bonded zones, border processing zones, export processing zones, scientific industrial parks, bonded warehouses and cargo distribution centers. Xinchang Guo (1987) divided the international free trade zones into four types: free ports, foreign trade zones, export processing zones and science and technology zones.

After the successful development of China's free trade zone, we began to learn from the successful experience of foreign countries. The development of China's free trade zone can be traced back to the Waigaoqiao Free Trade Zone established in 1990. After China's entry into WTO in 2001, in order to guide the development of processing trade, export processing zones have been set up in some key cities. Zhang Hanlin and Xinzhe Gai (2013) believe that since the implementation of the zone port linkage policy in 2003, various types of free trade zones have developed rapidly and become the export-oriented regional economic growth pole under the goods trade system.The global financial crisis broke out in 2008, and the global trade pattern began to change. During the Obama administration, the United States began to dominate the negotiations of the trans Pacific Partnership Agreement (TPP), the transatlantic trade and investment partnership agreement (TTIP) and the multilateral trade in Services Agreement (TISA), but China was not included in the three agreements. If the three major agreements are finally reached, it will be very detrimental to China's development. Although the TPP has been changed to CPTPP due to the withdrawal of the United States, the TTIP negotiations are completely stalled, and TISA is making slow progress. As a big export country, in order to alleviate the possible crisis and deal with the possible changes in the future, China began to vigorously develop more advanced free trade zones. The Third Plenary Session of the 18th CPC Central Committee proposed to innovate the opening-up mode from the perspective of top-level design. In 2013, Shanghai free trade zone arised at the historic moment. Yansheng Zhang (2013) proposed that the priority of Shanghai pilot free trade zone is to cope with the global change of building a high standard free trade area (FTA) by TPP and TTIP, and promote the internationalization and modernization of China's economy at a higher level, in a wider range and in a higher field. Youwen Zhang (2014) pointed that the key point of Shanghai free trade zone is to test the system innovation, to integrate with the international common rules, to promote the successful experience of Shanghai experiment to the whole country, and to force the reform of domestic economic system. At the end of 2014, in order to further expand the opening up and connect with "The Belt and Road" Initiative, China established the second batch of free trade zones in Tianjin, Guangzhou and Fujian. The first and second batch of free trade zones are mainly set up in coastal cities. In March 2017, China began to set up the third batch of free trade zones in Chongqing, Henan, Liaoning, Shaanxi, Hubei, Sichuan and Zhejiang, and the third batch of free trade zones began to be set up in inland areas. Each free trade zone has its own emphasis on specific positioning and undertakes different experimental tasks. In October 2018, Hainan Province began to establish a pilot Free Trade Zone, and in June 2020, it was positioned as a free trade port, becoming the most open form of free trade park in China. It is planned to initially build a free trade port in 2025 . As the free trade zones have achieved good results, in August 2019, six more pilot free trade zones will be established in Yunnan, Hebei, Guangxi, Jiangsu and Shandong. Since then, 18 provinces in China have free trade zones.

\footnotetext{
${ }^{2}$ At that time, the famous free trade zones were Naples, Trieste and Venice in Italy, Hamburg and Bremen in Germany, Dunkerque in France, Porto in Portugal and Copenhagen in Denmark.
} 
With regard to the existing research on the domestic free trade zone, the expert group of Shanghai University of international business and Economic Cooperation (2013) discussed in detail the development background and various policies of Shanghai Free Trade Zone, providing a lot of reference for the study of free trade zone. Finally, it puts forward some suggestions on how to develop the service trade between China and Shanghai from the perspective of service trade policy. Aizhen Chen\& Zhibiao Liu (2014) believe that the establishment of Shanghai free trade zone can optimize the allocation of resources and promote economic growth. Bi Yujiang, Haiyan Tang and Desheng Yin (2014) proposed how to promote the development of China's service trade through trade transformation on the basis of trade zone. Qi Chen \& Wei Liu (2014) believe that the establishment of Shanghai free trade zone has both positive and negative effects. On the one hand, the free trade zone can promote the effective allocation of resources, bring industrial agglomeration and scale economy, and enjoy the institutional dividend; on the other hand, the free trade zone may attract resources from other regions and have crowding out effect on other regions, which is not conducive to coordinated and balanced economic development, It is even not conducive to overall economic growth. Xiangdong Yang (2014) believes that the "pre access national treatment" and "negative list" mode of Shanghai free trade zone can promote the economic development in the free trade zone by reducing taxes, fees and transaction costs, so as to promote the economic development in the free trade zone.Bin Sheng (2017) evaluated the achievements of the established FTA from different perspectives, and put forward policy suggestions on how to better develop the FTA. In recent years, with the extension of the implementation time of the free trade zone, some scholars have begun to study the economic effect of the free trade zone from a quantitative perspective. Na Tan et al. (2015) used the counterfactual analysis method to believe that the establishment of Shanghai free trade zone has improved the industrial added value and total import and export volume of Shanghai, increasing by 2.69 and 6.73 percentage points respectively on a month-on-year basis.By using the method of nonlinear double difference and breakpoint regression, Houjun Xiang\& Kang He (2016) analyzed the trade effect and capital flow of Shanghai Free Trade Zone, concluded that the free trade zone has a greater role in promoting imports, but not in exports. Lihui Wang \& Zhihong Liu (2017) used the panel data policy effect evaluation method and the composite control method to analyze the macro and micro economic indicators, and believed that the free trade zone had a positive economic effect on economic growth.. Bingsickle Liu\& Yue Wang (2018) used the synthetic control method to construct the "counterfactual" sample, believing that the establishment of Shanghai free trade zone can significantly promote the improvement of Shanghai's innovation level. Ruidong Han et al. (2019) studied the impact of the establishment of Shanghai, Tianjin, Guangdong and Fujian free trade zones on cross-border capital flows by using the synthetic control method, and concluded that the impact of free trade zones on ODI is greater than that of FDI. Based on the 2016 customs data, Lili Wang (2019) conducted a comparative study on Shanghai free trade zone and concluded that Shanghai free trade zone has played a more obvious role in promoting trade, but there are also problems such as single trade varieties and insufficient participation of domestic enterprises.

The research on the trade effect of the pilot free trade zone is mostly carried out from the quantitative point of view, and it is believed that the zones will have a mre obvious trade promotion effect. However, most of the articles on the trade effect of the free trade zone mainly focus on the Shanghai Free Trade Zone, the research on other free trade zones is relatively less. The original intention of the development of China's free trade zone is to carry out institutional test, make trade rules better in line with international rules, further reform and opening up, and make China better integrated into international trade.In view of the limitations of the existing research, this paper attempts to improve the research on the trade effect of the free trade zone from the following two aspects: (1) This paper studies the trade effect of 11 free trade zones established in 2017 and before, overcoming the limitations of the study of Shanghai single free trade zone.(2) This paper uses the difference in difference method to measure the overall trade effect of the free trade zone from the perspective of total trade, import and export, and analyzes the heterogeneity of the trade effect of each free trade zone with the synthetic control method.

Based on the statistics of the total trade and growth rate of the provinces where the free trade zone is located, tables 2 and 3 are obtained. Through the analysis, we can draw the following conclusions: (1) Except Tianjin and Henan, the import and export growth rate of the provinces where the free trade zone is established is significantly faster than that of other provinces in China. (2) The proportion of the provinces where the free trade zone is located in the national import and export has been growing before 2016, but has declined since 2016. (3) After the United States and China launched trade in 2018, the four free trade zones established in the first and second batch were more impacted, and their import and export growth rates were slower than the national growth rate. 
Table 1. Summary of import and export units of cities in 2013-2019 US million dollars

\begin{tabular}{lccccccc}
\hline & 2013 & 2014 & 2015 & 2016 & 2017 & 2018 & 2019 \\
\hline National others & $2,545,656$ & $2,640,190$ & $2,487,050$ & $2,335,639$ & $2,553,568$ & $2,827,642$ & $2,768,206$ \\
\hline Shanghai & 441,268 & 466,400 & 449,241 & 433,768 & 476,197 & 515,680 & 493,890 \\
\hline Tianjin & 128,502 & 133,886 & 114,283 & 102,656 & 112,919 & 122,557 & 106,650 \\
\hline Guangdong & $1,091,581$ & $1,076,584$ & $1,022,496$ & 955,298 & $1,006,678$ & $1,084,465$ & $1,036,183$ \\
\hline Fujian & 169,321 & 177,408 & 168,846 & 156,826 & 171,020 & 187,407 & 193,119 \\
\hline Henan & 59,957 & 64,972 & 73,781 & 71,213 & 77,630 & 82,814 & 82,474 \\
\hline Hubei & 36,380 & 43,040 & 45,553 & 39,389 & 46,337 & 52,782 & 57,146 \\
\hline Liaoning & 114,478 & 113,998 & 95,947 & 86,557 & 99,595 & 114,601 & 105,280 \\
\hline Shaanxi & 20,128 & 27,364 & 30,499 & 29,947 & 40,203 & 53,305 & 51,050 \\
\hline Sichuan & 64,575 & 70,203 & 51,189 & 49,306 & 68,106 & 89,921 & 98,060 \\
\hline Zhejiang & 335,789 & 355,040 & 346,784 & 336,576 & 377,907 & 432,360 & 447,232 \\
\hline Chongqing & 68,692 & 95,432 & 74,467 & 62,754 & 66,601 & 79,017 & 83,970 \\
\hline Hainan & 14,985 & 15,863 & 13,967 & 11,348 & 10,374 & 12,734 & 13,153 \\
\hline Proportion of free trade & $61.2 \%$ & $61.4 \%$ & $62.9 \%$ & $63.4 \%$ & $62.2 \%$ & $61.2 \%$ & $60.5 \%$ \\
\hline Source: acco
\end{tabular}

Source: according to the data of National Bureau of statistics

The reasons for the above conclusions may be as follows: (1) The free trade zone can promote the development of local total trade and promote the rapid growth of import and export. The reason why the growth rate of import and export of Tianjin and Henan free trade zone is slower than that of the whole country may be that although Tianjin established the Free Trade Zone in 2015, the explosion of Tianjin port in 2015 had a great impact on import and export, resulting in a significant decline in the growth rate of import and export in 2015 and 2016, which was significantly slower than the national average level. Henan has a vast territory, Although the import and export of the free trade zone can grow rapidly, it can not drive the growth of import and export of the whole province. It may not be appropriate to analyze Henan pilot free trade zone with provincial data. (2) In 2016, China's main trade partner, the European Union, was in a recession, and the economic relationship between China and the United States began to deteriorate gradually, resulting in a decline in China's overall import and export. However, the provinces where the pilot free trade zone is located were more affected by the impact of external environment, which led to a decline in the proportion of imports and exports in the whole country in 2017. (3) In the free trade zones, the first and second batch of provinces are economically developed regions in China, which are also most affected by Sino US trade frictions, resulting in a slower growth rate of import and export than other provinces in the country.

To sum up, the author believes that the provincial data may not be able to reflect the trade effect of the pilot free trade zone. According to the analysis of the first part, the author divides each area of the free trade zone into specific cities, and analyzes the trade effect of the pilot free trade zone with the data of prefecture level city, so as to measure the trade effect of each area of the free trade zone more accurately and make the conclusion more accurate.

Table 2. changes in import and export growth rate of provinces and cities where the free trade zone is located from 2013 to 2019

\begin{tabular}{l|c|c|c|c|c|c|c}
\hline & 2013 & 2014 & 2015 & 2016 & 2017 & 2018 & 2019 \\
\hline $\begin{array}{l}\text { National } \\
\text { others }\end{array}$ & $9.1 \%$ & $3.7 \%$ & $-5.8 \%$ & $-6.1 \%$ & $9.3 \%$ & $10.7 \%$ & $-2.1 \%$ \\
\hline Shanghai & $1.1 \%$ & $5.7 \%$ & $-3.7 \%$ & $-3.4 \%$ & $9.8 \%$ & $8.3 \%$ & $-4.2 \%$ \\
\hline Tianjin & $11.1 \%$ & $4.2 \%$ & $-14.6 \%$ & $-10.2 \%$ & $10.0 \%$ & $8.5 \%$ & $-13.0 \%$ \\
\hline Guangdong & $10.9 \%$ & $-1.4 \%$ & $-5.0 \%$ & $-6.6 \%$ & $5.4 \%$ & $7.7 \%$ & $-4.5 \%$ \\
\hline Fujian & $8.6 \%$ & $4.8 \%$ & $-4.8 \%$ & $-7.1 \%$ & $9.1 \%$ & $9.6 \%$ & $3.0 \%$ \\
\hline Henan & $15.9 \%$ & $8.4 \%$ & $13.6 \%$ & $-3.5 \%$ & $9.0 \%$ & $6.7 \%$ & $-0.4 \%$ \\
\hline Hubei & $13.8 \%$ & $18.3 \%$ & $5.8 \%$ & $-13.5 \%$ & $17.6 \%$ & $13.9 \%$ & $8.3 \%$ \\
\hline Liaoning & $10.0 \%$ & $-0.4 \%$ & $-15.8 \%$ & $-9.8 \%$ & $15.1 \%$ & $15.1 \%$ & $-8.1 \%$ \\
\hline Shaanxi & $36.0 \%$ & $36.0 \%$ & $11.5 \%$ & $-1.8 \%$ & $34.2 \%$ & $32.6 \%$ & $-4.2 \%$ \\
\hline Sichuan & $9.2 \%$ & $8.7 \%$ & $-27.1 \%$ & $-3.7 \%$ & $38.1 \%$ & $32.0 \%$ & $9.1 \%$ \\
\hline Zhejiang & $7.5 \%$ & $5.7 \%$ & $-2.3 \%$ & $-2.9 \%$ & $12.3 \%$ & $14.4 \%$ & $3.4 \%$ \\
\hline Chongqing & $29.1 \%$ & $38.9 \%$ & $-22.0 \%$ & $-15.7 \%$ & $6.1 \%$ & $18.6 \%$ & $6.3 \%$ \\
\hline Hainan & $4.6 \%$ & $5.9 \%$ & $-12.0 \%$ & $-18.7 \%$ & $-8.6 \%$ & $22.7 \%$ & $3.3 \%$ \\
\hline Dat sour & & & & &
\end{tabular}

Data source: the author collates and calculates according to the data of National Bureau of statistics 


\section{Model Construction and Data Description}

\section{(1) Model construction}

In order to measure the trade effect brought by the Free Trade Zone, the basic econometric model of this chapter is designed as follows:

$$
\begin{aligned}
& \text { Lntotal }_{i t}=\alpha_{0}+\alpha_{1} T \times G+\sum_{i=1}^{n} \beta X_{i t}+\mu_{i t}+v_{i t}+\varepsilon_{i t} \\
& \text { Lnimport }_{i t}=\beta_{0}+\beta_{1} T \times G+\sum_{i=1}^{n} \gamma X_{i t}+\mu_{i t}+v_{i t}+\eta_{i t} \\
& \text { Lnexport }_{i t}=\gamma_{0}+\gamma_{1} T \times G+\sum_{i=1}^{n} \delta X_{i t}+\mu_{i t}+v_{i t}+\zeta_{i t}
\end{aligned}
$$

In the above formula, the following tables I and $t$ represent the prefecture level cities and years where they are located. Intotal, lnimport and lnexport, as the explanatory variables, represent the total trade volume, import volume and export volume of each prefecture level city respectively. X represents a set of control variables, including per capita GDP (lnGDP), fixed asset investment (lninvest), foreign direct investment (lnfidi), total retail sales of consumer goods (lnlingshou), exchange rate (lnhuilv), and population density (lnpop). $\mu_{i t}$ and $v_{i t}$ are represented regional and temporal fixed effects respectively. $\mathrm{T} \times \mathrm{G}$ is a dummy variable, $\mathrm{T}$ represents the time when the free trade zone was established. If the free trade zone has been established, the value is 1 , otherwise it is zero; $G$ represents whether it is a free trade zone, if it is a free trade zone, the value is 1 , otherwise it is 0 . Where coefficient $\alpha_{1} 、 \beta_{1} 、 \gamma_{1}$ is the most concerned variable in this paper, and the coefficient reflects whether the prefecture level city where the free trade zone is located has a trade promotion effect.

(2) Description and data source of variables

The explained variables are measured from three aspects: total trade, import and export. This paper uses the logarithm of the total trade, the logarithm of the total import and export of each city to test the influence of the establishment of the free trade zone on the trade. It is generally believed that the higher the per capita GDP and fixed asset investment, the greater the trade import and export volume. This paper takes the logarithm of per capita GDP and fixed asset investment as explanatory variables. The higher the foreign investment is, the closer it is to the international market. Consumer goods and total retail sales can be used to measure the domestic trade situation. The more developed the domestic trade, the higher the total import and export volume, The logarithm of the actual use of FDI and the logarithm of total retail sales of consumer goods are used to explain the impact on trade volume. The high or low exchange rate will generally have a direct impact on international trade. Cities with high population density tend to be more developed in import and export. The logarithm of exchange rate and the logarithm of population per square kilometer are used as explanatory variables to explain the changes of international trade.

In this paper, 288 prefecture level cities in mainland China from 2004 to 2018 are selected as the research samples. The original variable data are obtained from the statistical year books of various cities and the official website of the National Bureau of statistics of China. The author obtains the corresponding data from the CEIC China statistical database and the website of the National Bureau of statistics. Due to the serious lack of data of prefecture level cities before 2004 and the latest year of 2019, the author selected the data from 2004 to 2018 as the research object, deleted the individual prefecture level cities with more serious missing data, supplemented the individual missing data, and finally formed the balance panel data of 262 prefecture level cities. Due to the lack of fixed asset investment data of most cities in 2018 in the city statistical yearbook, this paper calculates the fixed asset investment amount in 2018 by using the growth rate of fixed asset investment of each city in the statistical yearbook of each province or municipality directly under the central government. Some provincial statistical yearbooks do not publish the growth rate of urban fixed asset investment. This paper uses the statistical bulletin issued by prefecture level cities to supplement the fixed asset investment in $2018^{3}$ 。 The statistical characteristics of the main variables involved in this paper are shown in table 6-3.

\footnotetext{
3 The statistical yearbooks of Fujian, Inner Mongolia, Yunnan, Hebei, Guizhou, Jilin, Hunan and other provinces failed to find the growth rate of urban fixed asset investment in 2018. The statistical data published by prefecture level cities were used to calculate the urban fixed asset investment.
} 
Table 3. descriptive statistics of main variables

\begin{tabular}{l|l|l|l|l|l}
\hline \multirow{2}{*}{\begin{tabular}{l} 
variable \\
\cline { 2 - 6 } \\
Sumples
\end{tabular}} & \multicolumn{2}{l}{ average value } & \multicolumn{2}{l}{$\begin{array}{l}\text { standard } \\
\text { deviation }\end{array}$} \\
\hline Lntotal & 3930 & 4.524 & 2.009 & -1.986 & 10.438 \\
\hline Lnimport & 3930 & 3.189 & 2.418 & -7.13 & 10.03 \\
\hline Lnexport & 3930 & 4.012 & 2.024 & -4.900 & 9.849 \\
\hline Lnrgdp & 3930 & 10.271 & 0.761 & 7.847 & 12.281 \\
\hline Lnhuilv & 3930 & 1.931 & 0.098 & 1.815 & 2.113 \\
\hline Lninvest & 3930 & 11.084 & 1.150 & 7.661 & 14.995 \\
\hline Lnlingshou & 3930 & 3.625 & 1.125 & 0.312 & 7.144 \\
\hline Lnfdi & 3930 & 5.203 & 1.782 & 0.000 & 10.099 \\
\hline Lnpop & 3930 & 5.934 & 0.952 & 1.755 & 8.783 \\
\hline
\end{tabular}

\section{Empirical Results and Robustness Test}

This section plans to use the differerce in difference method to check the policies of the pilot Free Trade Zone, and conduct benchmark regression according to equations (1) - (3). However, before the return, it is necessary to check whether the double difference method is applicable; Secondly, to conduct a robust test on the results of benchmark regression; Thirdly, to discuss the mechanism of the free trade zone policy on trade.

(1) Applicability test of difference in difference method

The purpose of using the difference in difference method is to eliminate the influence of some difficult to observe variables in the macro environment. The method needs to satisfy two basic assumptions: first, the establishment of the pilot free trade zone is not directly affected by the local import and export trade, that is, the establishment of the free trade zone needs to meet the "random" assumption in terms of time; second, the establishment of the pilot free trade zone should meet the "random" assumption, Cities with free trade zones and cities without pilot free trade zones meet the hypothesis of "parallel trend" in import and export trade.

First of all, it tests the random hypothesis of the establishment time of the pilot free trade zone. The free trade zones investigated in this paper are mainly divided into three groups: Shanghai pilot free trade zone was the first batch in 2013, Tianjin, Guangdong and Fujian free trade zones were the second batch in 2015, and Henan, Hubei, Liaoning, Shaanxi, Sichuan, Zhejiang and Chongqing pilot free trade zones in 2017 were the third batch. The establishment of the free trade zone is not directly affected by the local import and export trade, that is, the establishment of the pilot Free Trade Zone meets the exogenous hypothesis to a certain extent. Based on the practice of Guo Feng, Xiong Ruixiang (2017) and Han Ruidong (2020) on the randomness of the establishment time of city commercial banks, the logit model is used to test whether the import and export trade is directly set up in the pilot free trade zone. Since the pilot free trade was set up in different batches, it was first carried out in Shanghai and then gradually extended to other regions. Therefore, it is divided into three batches according to different batches, with the second batch and later cities as the first batch of control group; the third batch and cities without free trade zone as the second batch of control group; the cities without free trade zone as the third batch of control group, and the standards of each batch selected as pilot area of pilot free trade zone are tested in turn. The results in table 6-4 are obtained. It can be found that the coefficients of total import and export, import and export are not significant, which indicates that the city's trade situation is not the main factor affecting the establishment of free trade zone. It can be inferred that the establishment of free trade zone basically meets the "randomness" hypothesis required by the double difference method. 
Table 4. random test of the establishment time of free trade zone

\begin{tabular}{|c|c|c|c|}
\hline \multirow{2}{*}{ Variable } & \multicolumn{3}{|c|}{ Batch of the Free Trade Zone } \\
\hline & Batch 1 & Batch 2 & Batch 3 \\
\hline Lntotal & $\begin{array}{l}-0.0005 \\
(0.002) \\
\end{array}$ & $\begin{array}{r}-0.0009 \\
(0.023) \\
\end{array}$ & $\begin{array}{c}0.065 \\
(0.052) \\
\end{array}$ \\
\hline Lnimport & $\begin{array}{c}0.0001 \\
(0.001) \\
\end{array}$ & $\begin{array}{c}-0.001 \\
(0.080) \\
\end{array}$ & $\begin{array}{c}-0.032 \\
(0.019) \\
\end{array}$ \\
\hline Lnexport & $\begin{array}{c}-0.0001 \\
(0.001) \\
\end{array}$ & $\begin{array}{c}0.007 \\
(0.017) \\
\end{array}$ & $\begin{array}{c}-0.003 \\
(0.037) \\
\end{array}$ \\
\hline Lnrgdp & $\begin{array}{c}-0.006 \\
(0.004)\end{array}$ & $\begin{array}{l}0.035^{* * *} \\
(0.017)\end{array}$ & $\begin{array}{l}0.088^{* * * *} \\
(0.033)\end{array}$ \\
\hline Lnhuilv & $\begin{array}{c}-0.092^{* * *} \\
(0.020)\end{array}$ & $\begin{array}{l}0.300^{* * *} \\
(0.106)\end{array}$ & $\begin{array}{c}0.362 \\
(0.971) \\
\end{array}$ \\
\hline Lninvest & $\begin{array}{c}-0.007^{* * * *} \\
(0.002)\end{array}$ & $\begin{array}{c}-0.015 \\
(0.012) \\
\end{array}$ & $\begin{array}{c}0.003 \\
(0.022) \\
\end{array}$ \\
\hline Lnfdi & $\begin{array}{c}0.0005 \\
(0.001) \\
\end{array}$ & $\begin{array}{c}0.006 \\
(0.005) \\
\end{array}$ & $\begin{array}{c}0.031 * * * \\
(0.010) \\
\end{array}$ \\
\hline Lnpop & $\begin{array}{l}0.00005 \\
(0.001) \\
\end{array}$ & $\begin{array}{c}0.027 * * * \\
(0.009) \\
\end{array}$ & $\begin{array}{c}0.030^{*} \\
(0.017) \\
\end{array}$ \\
\hline Year FE & $\mathrm{Y}$ & $\mathrm{Y}$ & $\mathrm{Y}$ \\
\hline Province FE & $\mathrm{Y}$ & $\mathrm{Y}$ & $\mathrm{Y}$ \\
\hline Number & 2620 & 786 & 524 \\
\hline
\end{tabular}

Note: () is the robust standard error of urban clustering adjustment, ***,**, which are significant at $1 \%, 5 \%$ and $10 \%$ levels respectively

Secondly, the difference indifference method is used to investigate the free trade zone policy, and it is necessary to check whether it meets the parallel trend. That is to say, the explained variables of the experimental group (cities with free trade zones) and the control group (cities without free trade zones) should have the same development path before the implementation of the policy, so that the control group can be better regarded as the counterfactual of the experimental group. If the implementation time of the free trade zone is a single time point, we can use the curve to observe whether the experimental group and the control group meet the parallel trend. However, different FTZs are not established at the same time point. At this time, parallel trend test is carried out. Referring to Thorsten Beck (2010) and weizeng Sun (2018) using the method of counterfactual analysis, the implementation time of all free trade zones is advanced or postponed at the same time, and whether the impact of free trade zone policies on import and export is significant. Using this method, if the effect of the early implementation of the free trade zone on import and export is not significant, and the lagging implementation policy can significantly affect the import and export volume, then it is considered that the free trade zone policy before the implementation of the parallel trend. The regression equation of this method to test the parallel trend is as follows:

$$
\begin{aligned}
& \text { Lntotal }_{i t}=\beta_{0}+\beta_{1} D_{i t}^{-9+} \beta_{2} D_{i t}^{-8}+\cdots+\beta_{11} D_{i t}^{+1}+\sum_{i=1}^{n} \eta X_{i t}+\mu_{i t}+v_{i t}+\varepsilon_{i t} \\
& \text { Lnimport }_{i t}=\beta_{0}+\beta_{1} D_{i t}^{-9+} \beta_{2} D_{i t}^{-8}+\cdots+\beta_{11} D_{i t}^{+1}+\sum_{i=1}^{n} \eta X_{i t}+\mu_{i t}+v_{i t}+\varepsilon_{i t} \\
& \text { Lnexport }_{i t}=\beta_{0}+\beta_{1} D_{i t}^{-9+} \beta_{2} D_{i t}^{-8}+\cdots+\beta_{11} D_{i t}^{+1}+\sum_{i=1}^{n} \eta X_{i t}+\mu_{i t}+v_{i t}+\varepsilon_{i t}
\end{aligned}
$$

Among them, Lntotal $_{i t}$ 、 Lnimport ${ }_{i t}$ and Lnexport ${ }_{i t}$ represent the logarithm of the total trade volume, import volume and export volume of region I in the T year respectively. $\mathrm{D}$ is the time dummy variable, representing the number of periods in advance or lagging behind the policy. The reason why we choose to use the advanced phase 9 and the lag phase 1 is because the data used are from 2004 to 2018, and the earliest established Shanghai free trade zone is 2013, and seven of the sample in this paper were established in 2017. In order to ensure that all FTZs are in the period of advance and lag, we choose 9 periods in advance and 1 period in lag.

Figure 1 shows the parallel trend test of multi period did with $95 \%$ confidence interval and observed estimation coefficient $\beta$ According to the results, if the impact of policy advance on trade fails to pass the significance test, and the policy lag can pass the significance test, it shows that the experimental group and the control group meet the parallel trend hypothesis before the implementation of the policy. 

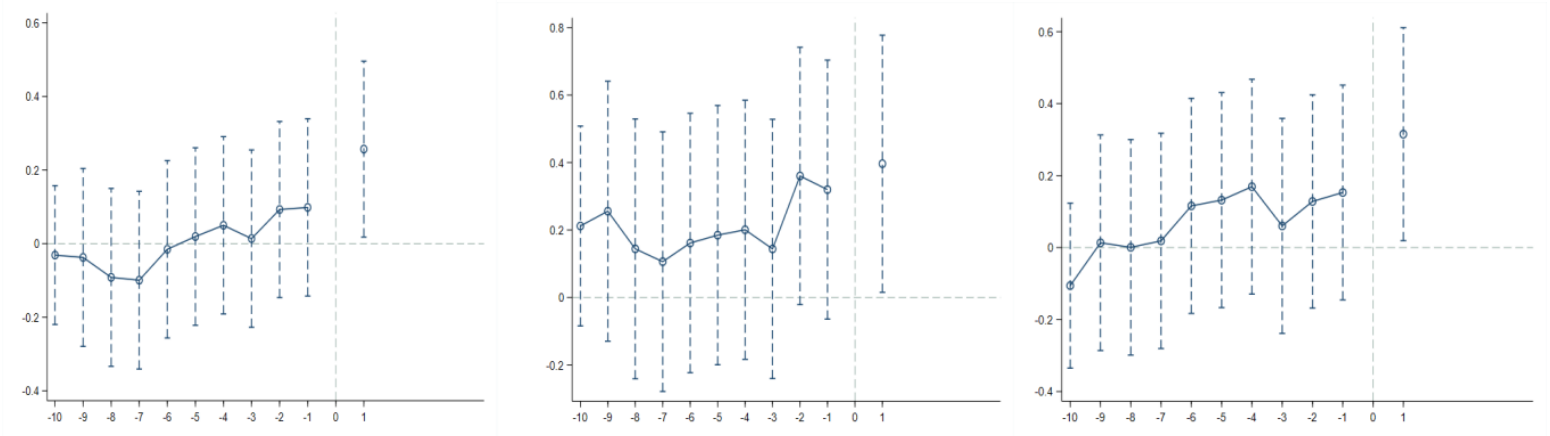

Figure 1. Establishment of free trade zone and import and export volume, import volume and export volume

\section{(2) Baseline regression results}

In order to reduce the influence of heteroscedasticity on the empirical results, the natural logarithm is adopted for other variables except dummy variables and economic growth rate indicators. In order to test whether the establishment of the pilot free trade zone will bring about the growth effect of trade, this chapter makes regression estimation according to the model design of equations (1) - (3).Table 6 reports the estimated results of the impact of free trade zone policies on total trade, import and export. Among them, columns 1-2 are estimated results of total trade, columns 3-4 and 5-6 are estimated results of import and export respectively. The first, third and fifth columns control the time effect and provincial effect, and the second, fourth and sixth columns control the time effect and individual effect. According to the results, the implementation of the free trade zone has a significant positive impact on the growth of import and export regardless of the provincial effect or individual effect, indicating that the pilot free trade zone has a certain promoting effect on the total trade. Through the analysis of import and export, the implementation of the pilot free trade zone has a positive impact on both import and export, but the impact of the implementation of the policy on import failed to pass the significance test, only export passed the significance test. The possible reasons are as follows: (1) As the policy of the free trade zone is not only trade facilitation but also investment facilitation, many foreign enterprises have entered the free trade zone, and the upstream and downstream enterprises supporting it have also entered the region, which has led to the increase of the total trade volume through the front, back and side effects.(2) The free trade zone has promoted the increase of total trade through institutional reform, speeding up customs clearance and reducing tariff and non-tariff barriers.(3) On the one hand, the reduction of trade barriers promotes the development of import trade; on the other hand, investment facilitation makes the goods that need to be imported be transferred to the free trade zone for production, thus reducing the import volume; the area of each free trade zone is smaller. Most of the imported goods will flow into the non free trade zone and re export trade. These commodities do not need to be declared when they enter the free trade zone, so the free trade zone policy does not show a significant role in promoting imports. (4) The promotion effect of free trade zone on export is obvious, which is mainly due to the investment facilitation and negative list system attracting a large number of foreign enterprises. Moreover, the enterprises in the free trade zone also enjoy the preferential policies of VAT, consumption tax and enterprise income tax exemption and exemption, and are not limited by the license quota, and the customs clearance speed also has obvious advantages. Therefore, the free trade zone policy has a significant role in promoting exports. 
Table 5. estimated results of trade effects of pilot free trade zones

\begin{tabular}{|c|c|c|c|c|c|c|}
\hline \multirow{2}{*}{ variable } & \multicolumn{2}{|c|}{ Import and export volume } & \multicolumn{2}{|c|}{ Imports } & \multicolumn{2}{|c|}{ Export volume } \\
\hline & (1) & $(2)$ & (3) & (4) & $(5)$ & (6) \\
\hline \multirow[b]{2}{*}{$\mathrm{T} \times G$} & $0.168^{* *}$ & $0.147^{\text {** }}$ & 0.095 & 0.067 & $0.164^{* *}$ & $0.138^{*}$ \\
\hline & $(0.069)$ & $(0.067)$ & $(0.106)$ & $(0.103)$ & $(0.082)$ & $(0.081)$ \\
\hline \multirow{2}{*}{ Lnrgdp } & $0.974^{* * * *}$ & $0.855^{* * * 2}$ & $1.254^{* * * *}$ & $1.035^{* * * *}$ & $0.932^{* * * * 2}$ & $0.881^{* \ldots * \cdots}$ \\
\hline & $(0.061)$ & $(0.067)$ & $(0.093)$ & $(0.104)$ & $(0.070)$ & $(0.081)$ \\
\hline \multirow{2}{*}{ Lnhuilv } & $2.314^{* * * * *}$ & 0.741 & $2.926^{* * * * 2}$ & 0.432 & $3.299^{\text {*****6\% }}$ & 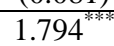 \\
\hline & $(0.409)$ & $(0.432)$ & $(0.626)$ & $(0.671)$ & $(0.474)$ & $(0.523)$ \\
\hline \multirow{2}{*}{ Lninvest } & $0.204^{* * * *}$ & $0.138^{* * * *}$ & 0.024 & -0.061 & $0.324^{* * * *}$ & $0.220^{\text {*6\% }}$ \\
\hline & $(0.029)$ & $(0.030)$ & $(0.045)$ & $(0.046)$ & $(0.034)$ & $(0.036)$ \\
\hline \multirow{2}{*}{ Lnfdi } & $0.039^{* * * *}$ & 0.015 & $0.069^{* * * *}$ & $0.034^{* * *}$ & $0.047^{* * * *}$ & 0.016 \\
\hline & $(0.039)$ & $(0.011)$ & $(0.016)$ & $(0.016)$ & $(0.013)$ & $(0.013)$ \\
\hline \multirow{2}{*}{ Lnpop } & $0.090^{* * * * *}$ & 0.013 & $0.114^{* * * *}$ & 0.001 & $0.134^{* * * *}$ & 0.044 \\
\hline & $(0.025)$ & $(0.026)$ & $(0.039)$ & $(0.041)$ & $(0.030)$ & $(0.032)$ \\
\hline \multirow{2}{*}{ Cons_ } & -9.474 & -3.384 & -12.077 & -2.441 & -14.594 & -8.765 \\
\hline & $(1.545)$ & $(1.535)$ & $(2.335)$ & (2.292) & (1.716) & (1.786) \\
\hline Fixed time & $\mathrm{Y}$ & $\mathrm{Y}$ & $\mathrm{Y}$ & $\mathrm{Y}$ & $\mathrm{Y}$ & $\mathrm{Y}$ \\
\hline $\begin{array}{c}\text { Fixed } \\
\text { Province }\end{array}$ & $\mathrm{Y}$ & Y & Y & Y & Y & Y \\
\hline $\begin{array}{l}\text { Urban } \\
\text { fixation }\end{array}$ & $\mathrm{N}$ & Y & $\mathrm{N}$ & $\mathrm{Y}$ & $\mathrm{N}$ & $\mathrm{Y}$ \\
\hline Within- $R^{2}$ & 0.581 & 0.585 & 0.349 & 0.355 & 0.490 & 0.494 \\
\hline $\begin{array}{c}\text { Number of } \\
\text { samples }\end{array}$ & 3930 & 3930 & 3930 & 3930 & 3930 & 3930 \\
\hline
\end{tabular}

Note: () is the robust standard error of urban clustering adjustment, $* * *, * *$, which are significant at $1 \%, 5 \%$ and $10 \%$ levels respectively

Analyze the influence of other control variables on import and export trade. Whether it is time effect and province effect, or time effect and individual effect, per capita GDP can obviously promote total trade, import and export. When controlling the time effect and provincial effect, the exchange rate passed the significance test, but when the individual effect was controlled, the exchange rate only passed the significance test of export promotion. When the exchange rate becomes larger, that is, depreciation, it is more conducive to export, and the effect on import is uncertain, which conforms to economic common sense. Fixed assets investment has a significant effect on the total trade and export, but the effect on import has not passed the significance test, which shows that the fixed assets investment can promote the export, and then increase the total import and export. The promotion effect of FDI on import has passed the significance test. Under the control of provincial effect, foreign investment can promote export through the promotion effect. When controlling the provincial effect and time effect, the promotion effect of population density on import and export, import and export all passed the significance test, but when the individual effect and time effect were controlled, the population density could no longer pass the significance test, that is to say, the greater the population density in different provinces, the more obvious the promotion effect of import and export.

\section{(3) Robustness test}

Whether the positive effect of the sub section on the promotion of free trade in the region is tested. In order to test whether the conclusion in the previous section is robust and credible, this paper tests from two aspects: replacing the explained variables and excluding the pilot free trade zone where the municipality is located.

First, replace the core explanatory variables. In the previous section, we use dummy variables to measure whether the free trade zone policy has been implemented. Referring to the research of Zheng et al. (2016) and ye xiuqun (2018) on free trade zones such as free trade zones and export processing zones, we use the area to represent the scale of free trade zones. In this paper, after the establishment of the free trade zone, the size of the free trade zone of the city where it is located is used to measure the policy of the pilot free trade zone. Table 7 is obtained after replacing the core explanatory variables, and the regression results are relatively stable. The total trade volume can be explained by the size of the area after the establishment of the free trade zone; however, the policy of the free trade zone still has no significant impact on imports; the larger the area of the free trade zone, the greater the export volume, which can pass the significance test. 
Table 6. estimated results of trade effects of free trade areas in terms of area

\begin{tabular}{|c|c|c|c|c|c|c|}
\hline \multirow{2}{*}{ variable } & \multicolumn{2}{|c|}{ total imports and exports } & \multicolumn{2}{|c|}{ Imported } & \multicolumn{2}{|c|}{ exit } \\
\hline & (1) & (2) & (3) & (4) & (5) & (6) \\
\hline \multirow{2}{*}{ Lnmianji } & $0.043^{* *}$ & $0.037^{* *}$ & 0.029 & 0.021 & $0.040^{* *}$ & $0.033^{*}$ \\
\hline & $(0.017)$ & $(0.017)$ & $(0.027)$ & $(0.026)$ & $(0.021)$ & $(0.020)$ \\
\hline \multirow{2}{*}{ Lnrgdp } & $0.974^{* * * *}$ & $0.856^{* * * *}$ & $1.254^{* * * *}$ & $1.035^{* * * *}$ & $0.9323^{* * *}$ & $0.882^{* * *}$ \\
\hline & $(0.061)$ & $(0.067)$ & $(0.093)$ & $(0.105)$ & $(0.070)$ & $(0.081)$ \\
\hline \multirow{2}{*}{ Lnhuilv } & $2.320^{* * *}$ & $0.744^{*}$ & $2.941^{* * *}$ & 0.446 & $3.301^{* * * *}$ & $1.796^{* * *}$ \\
\hline & $(0.409)$ & $(0.432)$ & $(0.626)$ & $(0.714)$ & $(0.475)$ & $(0.522)$ \\
\hline \multirow{2}{*}{ Lninvest } & $0.205^{* * *}$ & $0.138^{* * * *}$ & 0.024 & -0.061 & $0.324^{* * * *}$ & $0.220^{* * *}$ \\
\hline & $(0.029)$ & $(0.030)$ & $(0.045)$ & $(0.046)$ & $(0.034)$ & $(0.036)$ \\
\hline \multirow{2}{*}{ Lnfdi } & $0.039^{* * *}$ & 0.015 & $0.069^{* * *}$ & $0.034^{* *}$ & $0.047^{* * *}$ & 0.016 \\
\hline & $(0.011)$ & $(0.011)$ & $(0.017)$ & $(0.016)$ & $(0.013)$ & $(0.013)$ \\
\hline \multirow{2}{*}{ Lnpop } & $0.090^{* * *}$ & 0.013 & $0.113^{* * *}$ & -0.001 & $0.134^{* * *}$ & 0.044 \\
\hline & $(0.025)$ & $(0.026)$ & $(0.039)$ & $(0.041)$ & $(0.030)$ & $(0.032)$ \\
\hline \multirow{2}{*}{ Cons_ } & -9.494 & -3.399 & -12.114 & -2.473 & -14.605 & -8.774 \\
\hline & $(1.546)$ & $(1.477)$ & $(2.404)$ & $(2.384)$ & $(1.717)$ & $(1.786)$ \\
\hline Year Fixed & Y & Y & Y & Y & Y & Y \\
\hline Province FE & Y & $\mathrm{Y}$ & $\mathrm{Y}$ & Y & Y & Y \\
\hline Urban FE & $\mathrm{N}$ & $\mathrm{Y}$ & $\mathrm{N}$ & $\mathrm{Y}$ & $\mathrm{N}$ & $\mathrm{Y}$ \\
\hline Within- $R^{2}$ & 0.581 & 0.585 & 0.350 & 0.355 & 0.490 & 0.495 \\
\hline Number & 3930 & 3930 & 3930 & 3930 & 3930 & 3930 \\
\hline
\end{tabular}

Note: () is the robust standard error of urban clustering adjustment, ***,**,* which are significant at $1 \%, 5 \%$ and $10 \%$ levels respectively

Second, we should exclude the pilot free trade zones in Shanghai, Tianjin and Chongqing, and examine the impact of policies on trade. Since municipalities directly under the central government are generally regional economic centers, they have some natural advantages in terms of economy, politics and geographical location. In this way, eight free trade zones are reserved and distributed in 19 prefecture level cities. The difference in difference estimation method mentioned above is used for re estimation. The results are shown in Table 8.In each equation, the trade effects of the free trade zone policy on import and export, import and export are consistent with the previous estimates. The results show that the trade promotion effect of the pilot Free Trade Zone on the total amount of import and export and export is obvious, and has certain stability. 
Table 7. Estimated results of trade effects of FTZS excluding municipalities directly under the central government

\begin{tabular}{|c|c|c|c|c|c|c|}
\hline \multirow{2}{*}{ variable } & \multicolumn{2}{|c|}{ total imports and exports } & \multicolumn{2}{|c|}{ Imported } & \multicolumn{2}{|c|}{ exit } \\
\hline & (1) & (2) & (3) & (4) & (5) & (6) \\
\hline $\mathrm{T} \times G$ & $\begin{array}{l}0.189^{* *} \\
(0.075)\end{array}$ & $\begin{array}{l}0.169^{* *} \\
(0.073)\end{array}$ & $\begin{array}{c}0.078 \\
(0.117)\end{array}$ & $\begin{array}{c}0.051 \\
(0.114)\end{array}$ & $\begin{array}{l}0.203^{* *} \\
(0.090)\end{array}$ & $\begin{array}{l}0.178^{* *} \\
(0.088)\end{array}$ \\
\hline Lnrgdp & $\begin{array}{c}0.960^{* * * *} \\
(0.061)\end{array}$ & $\begin{array}{c}0.835^{* * * * *} \\
(0.067)\end{array}$ & $\begin{array}{l}1.247^{* * * * *} \\
(0.094)\end{array}$ & $\begin{array}{l}1.021^{* * * *} \\
(0.105)\end{array}$ & $\begin{array}{c}0.916^{* * * *} \\
(0.069)\end{array}$ & $\begin{array}{c}0.858^{* * * *} \\
(0.082)\end{array}$ \\
\hline Lnhuilv & $\begin{array}{c}2.268^{* * * *} \\
(0.412)\end{array}$ & $\begin{array}{c}0.653 \\
(0.436)\end{array}$ & $\begin{array}{l}2.918^{* * * *} \\
(0.632)\end{array}$ & $\begin{array}{c}0.365 \\
(0.679)\end{array}$ & $\begin{array}{c}3.256^{* * * *} \\
(0.478)\end{array}$ & $\begin{array}{l}1.700^{* * * *} \\
(0.527)\end{array}$ \\
\hline Lninvest & $\begin{array}{c}0.208^{* * * *} \\
(0.029)\end{array}$ & $\begin{array}{c}0.142^{* * * *} \\
(0.030)\end{array}$ & $\begin{array}{c}0.027 \\
(0.045)\end{array}$ & $\begin{array}{l}-0.059 \\
(0.047)\end{array}$ & $\begin{array}{c}0.330^{* * * *} \\
(0.035)\end{array}$ & $\begin{array}{c}0.225^{* * * *} \\
(0.036)\end{array}$ \\
\hline Lnfdi & $\begin{array}{c}0.039^{* * * *} \\
(0.011)\end{array}$ & $\begin{array}{c}0.015 \\
(0.011)\end{array}$ & $\begin{array}{c}0.070^{* * * * *} \\
(0.017)\end{array}$ & $\begin{array}{l}0.035^{* * *} \\
(0.016)\end{array}$ & $\begin{array}{c}0.046^{* * * *} \\
(0.013)\end{array}$ & $\begin{array}{c}0.016 \\
(0.013)\end{array}$ \\
\hline Lnpop & $\begin{array}{c}0.090^{* * * *} \\
(0.026)\end{array}$ & $\begin{array}{c}0.117 \\
(0.026)\end{array}$ & $\begin{array}{l}0.114^{* * * *} \\
(0.039)\end{array}$ & $\begin{array}{l}-0.001 \\
(0.041)\end{array}$ & $\begin{array}{c}0.134^{* * *} \\
(0.030)\end{array}$ & $\begin{array}{c}0.044 \\
(0.032)\end{array}$ \\
\hline Cons_ & $\begin{array}{c}-9.280 \\
(1.554)\end{array}$ & $\begin{array}{c}-3.033 \\
(1.488)\end{array}$ & $\begin{array}{c}-12.03 \\
(2.352)\end{array}$ & $\begin{array}{l}-2.175 \\
(2.316)\end{array}$ & $\begin{array}{c}-14.405 \\
(1.726)\end{array}$ & $\begin{array}{c}-8.383 \\
(1.800)\end{array}$ \\
\hline Fixed time & $\mathrm{Y}$ & $\mathrm{Y}$ & Y & $\mathrm{Y}$ & $\mathrm{Y}$ & Y \\
\hline $\begin{array}{c}\text { Fixed } \\
\text { Province }\end{array}$ & Y & $\mathrm{Y}$ & Y & $\mathrm{Y}$ & $\mathrm{Y}$ & $\mathrm{Y}$ \\
\hline Urban fixation & $\mathrm{N}$ & $\mathrm{Y}$ & $\mathrm{N}$ & $\mathrm{Y}$ & $\mathrm{N}$ & $\mathrm{Y}$ \\
\hline Within- $R^{2}$ & 0.580 & 0.584 & 0.347 & 352 & 0.489 & 0.493 \\
\hline $\begin{array}{c}\text { Number of } \\
\text { samples }\end{array}$ & 3885 & 3885 & 3885 & 3885 & 3885 & 3885 \\
\hline
\end{tabular}

Note: () is the robust standard error of urban clustering adjustment, $* * *, * *$, which are significant at $1 \%, 5 \%$ and $10 \%$ levels respectively

\section{(4) Mechanism analysis}

The establishment of the pilot free trade zone is closely related to the import and export trade, which has been analyzed from the theoretical level of trade creation and trade transfer. This part mainly analyzes how the pilot Free Trade Zone promotes the development of import and export trade from the perspectives of government system innovation, trade facilitation and investment facilitation.

1. Government system innovation. The original intention is to set up free trade zones throughout the country. In the summary part of the above established pilot Free Trade Zone, the development tasks of the free trade zone have been summarized. Bin Sheng (2017) believes that the FTZ has formed a complete set of independent innovation system, which can realize the transformation and upgrading of industries, technology and talents in the free trade zone; Bin Sheng also combed the specific promotion and replication systems of Shanghai, Tianjin, Guangdong and Fujian free trade zones. Using the counterfactual analysis method proposed by Hisao, Hua Yin \& Weihe Gao (2017) analyzed the "institutional dividend" effect of Shanghai free trade zone, and concluded that the institutional innovation of Shanghai free trade zone has long-term economic effects, and can promote the significant growth of Shanghai's GDP, investment, import and export. When studying the Shanghai free trade zone, Lili Wang (2019) believes that Shanghai has achieved a fair and efficient market access management foundation, and the role of the government is "regulation and service", forming a market-oriented, legal and international innovation system. Overall, the 11 FTZs studied in this paper have carried out institutional innovation according to their own pilot tasks. However, the core of the government system innovation of the 11 FTZs is to deregulate, improve the service level, and improve the business registration system and specific regulatory system. Its foreign trade system is more open to the outside world and promotes the development of its import and export system through a higher degree of innovation.

2. Trade facilitation. The trade facilitation system of the free trade zone can directly affect the import and export trade. Through the implementation of international trade single window management system, the application of the latest Internet technology, the construction of intelligent inspection port, the realization of intelligent customs clearance, and the encouragement of cross-border e-commerce, the free trade zone has accelerated the speed of customs clearance and reduced logistics costs. Guanghui Li (2017) believes that the four free trade zones established earlier have introduced a large number of trade facilitation measures based on the benchmark of 
international high-standard economic and trade rules, which has improved the customs clearance efficiency by more than 50\%. Each free trade zone has also given different tax preferences. Tariffs are not levied or reduced on some goods imported in the free trade zone, while lower enterprise income tax, personal income tax and value-added tax are levied on the encouraged industries. These measures promote the free flow of factors and the optimal allocation of resources, and then promote the import and export trade.

3. Investment facilitation. The free trade zone implements investment facilitation measures of pre access national treatment and negative list management system. The improvement of the level of its investment openness makes foreign-invested enterprises gather in the free trade zone. In 2013, when the first pilot free trade zone was established in Shanghai, the number of negative list items was 190, and then decreased year by year. By the end of the 2019 edition of the Special Administrative Measures for foreign investment access (negative list) (2019 Edition), the negative list management measures of the free trade zone have been reduced to 37. At the same time, the negative list system of the pilot free trade zone has been promoted nationwide, and has been reduced to 40 by 2019.The pilot free trade zone also provides various conveniences in investment management services. For example, Shanghai free trade zone provides system improvements such as "multiple certificates in one, one certificate one code" and "one port acceptance". Fujian Free Trade Zone implements the service mode of "one form declaration, one chapter approval and one day settlement" for enterprises, which saves time and cost for enterprises and makes the number of newly established enterprises increase rapidly. Investment facilitation increases the number of new enterprises, especially foreign-funded enterprises, in the free trade zone. The increase in the number of enterprises promotes the development of import and export trade and drives the growth of import and export trade volume.

\section{Heterogeneity Analysis}

\section{(1) Analysis of regional heterogeneity}

Based on the analysis of the trade effect of the Free Trade Zone, it is found that the promotion effect of the free trade zone on export is more obvious than on import. This part divides the 11 FTZs into the eastern region and the central and western region, and examines their trade effects respectively ${ }^{4}$ 。 To see whether there is heterogeneity, we use the same measurement method to get Table 8 . We can draw the following conclusions: (1) the central and western regions are consistent with the overall conclusion above, and the prefecture level cities where the pilot free trade zone is located play a more obvious role in promoting the export and total import and export.(2) The establishment of the pilot Free Trade Zone in the eastern region has led to a decline in exports, while the pilot free trade zone has no obvious effect on imports and total imports and exports.(3) The import effect of the central and western regions is obviously greater than that of the eastern region.

The possible reasons for the above results are as follows: (1) Compared with the eastern region, the overall economic scale of prefecture level cities in the central and western regions is smaller, and the level of economic development is generally lower than that of the eastern region. The local labor cost is lower than that in the East, and the investment and trade facilitation provided by institutional innovation is more conducive to attracting foreign capital for re export trade, which has a significant promoting effect on exports, and overall drives the growth of total import and export.(2) The possible reason is that the explosion in Tianjin port in 2015 had a great impact on the import and export. After excluding the Tianjin free trade area, the author found that the effect of the free trade zone on the export was no longer significant. After excluding Tianjin, it has not become significantly positive correlation, which may be due to the fact that the eastern free trade zone undertakes more functions of financial services, which has a significant effect on attracting foreign investment, mainly on imports and less on exports. This is consistent with Xiang Houjun's (2013) study of Shanghai pilot free trade zone that the impact of Free Trade Zone on export is not significant. In addition, it is also possible that the economy of the eastern free trade zone is relatively developed. Although the free trade zone has more preferential policies, it still can not drive the growth of import and export of the whole prefecture level city. Taking the East Zhuhai free trade zone of Guangdong Province as an example, the average annual growth rate of import and export of Zhuhai free trade zone since its establishment is $66.33 \%$ by 2019, but the growth rate of Zhuhai's import and export is slower than the national growth rate, and the growth rates of import and export in $2015-2018$ are - 12\%, - 7\%, $8 \%$

\footnotetext{
${ }^{4}$ This paper refers to the division method of the National Bureau of statistics. Specifically, the eastern pilot free trade zone includes six pilot free trade zones in Shanghai, Tianjin, Guangdong, Fujian, Zhejiang and Liaoning, and 11 prefecture level city areas, while the Western pilot free trade zone includes five pilot free trade zones, including Henan, Chongqing, Hubei, Sichuan and Shaanxi, and 11 prefecture level city areas.
} 
and 9\% respectively ${ }^{5}$ 。(3) In addition, the overall economic volume of prefecture level cities in the central and western regions is smaller than that in the eastern region, which can better reflect the trade promotion role of the pilot free trade zone.

Table 8. Analysis of regional heterogeneity

\begin{tabular}{|c|c|c|c|c|c|c|}
\hline \multirow{2}{*}{ variable } & \multicolumn{2}{|c|}{ total imports and exports } & \multicolumn{2}{|c|}{ Imported } & \multicolumn{2}{|c|}{ exit } \\
\hline & east & midwest & east & midwest & east & midwest \\
\hline $\mathrm{T} \times G$ & $\begin{array}{c}-0.078 \\
(0.060) \\
\end{array}$ & $\begin{array}{c}0.433^{* * * *} \\
(0.124) \\
\end{array}$ & $\begin{array}{c}0.018 \\
(0.099) \\
\end{array}$ & $\begin{array}{c}0.116 \\
(0.191) \\
\end{array}$ & $\begin{array}{c}-0.118^{* * *} \\
(0.058)\end{array}$ & $\begin{array}{l}0.462^{* * *} \\
(0.153)\end{array}$ \\
\hline $\begin{array}{c}\text { control } \\
\text { variable }\end{array}$ & $\mathrm{Y}$ & $\mathrm{Y}$ & $\mathrm{Y}$ & $\mathrm{Y}$ & $\mathrm{Y}$ & Y \\
\hline Cons_ & -6.254 & -14.749 & -12.148 & -17.923 & -7.727 & -20.433 \\
\hline Fixed time & $\mathrm{Y}$ & $\mathrm{Y}$ & $\mathrm{Y}$ & $\mathrm{Y}$ & $\mathrm{Y}$ & $\mathrm{Y}$ \\
\hline $\begin{array}{c}\text { Fixed } \\
\text { Province }\end{array}$ & Y & Y & Y & Y & $\mathrm{Y}$ & Y \\
\hline Within- $R^{2}$ & 0.707 & 0.555 & 0.476 & 0.315 & 0.700 & 0.462 \\
\hline Number & 1515 & 2415 & 1515 & 2415 & 1515 & 2415 \\
\hline
\end{tabular}

Note: () is the robust standard error of urban clustering adjustment, $* * *, * *$, which are significant at $1 \%, 5 \%$ and $10 \%$ levels respectively

(2) Analysis on the heterogeneity of each trade zone

In the benchmark analysis part of this paper, it has been verified that the pilot free trade zone can significantly promote the import and export volume and export volume, but whether there is heterogeneity in the trade effect of each region needs to be investigated separately. In this part, the synthetic control method proposed by Abadie \& gardeazabal (2003) is used to study the trade effects of the pilot free trade zones in different regions. This method can avoid the subjectivity of the selection of control groups and the endogenous problems of the policy itself (see Abadie et al., 2010).The idea of this method is to construct the "counterfactual" object of the experimental group according to the data of the control group, and measure the effect of the policy by comparing the difference between the real experimental group and the experimental group fitted with the control group data.

1. Model design of synthetic control method

This section deals with import and export (Total) As an example to illustrate the process of building the model.

Suppose we can observe $\mathrm{W}+1$ prefecture level cities in thet $\in[1, \mathrm{~T}]$ Among the import and export data during the period, $\mathrm{w}$ area is the control group without pilot Free Trade Zone, and the remaining one is the experimental group with free trade zone.Total ${ }_{i t}^{K}$ For the first timei $\in[1, W+1]$ If there is no pilot Free Trade Zone on time point $t$, the import and export data of each region will be calculated,Total $L_{i t}^{L}$ Denotes the119 regionsIf the pilot free trade zone is set up at time point $\mathrm{t}$, the import and export data will be obtained. $\mathrm{T}_{0} \mathrm{It}$ is the specific time for region I to establish the pilot Free Trade Zone, which meets the requirements of $1 \leq \mathrm{T}_{0} \leq \mathrm{T}$, int $\in\left[1, \mathrm{~T}_{0}\right] \operatorname{Import}$ and export will not be affected by the pilot free trade zone policy.stayt $\in\left[\mathrm{T}_{0}, \mathrm{~T}\right] \mathrm{Time}$, order $\beta_{i t}=$ Total $_{i t}^{L}-$ Total $_{i t}^{K}$ It refers to the trade impact of the establishment of pilot Free Trade Zone in region I.For the import and export data of the location of the pilot Free Trade Zone, we can only observe the data after the establishment of the pilot Free Trade Zone, but not the import and export data of the place without the pilot free trade zone.Therefore, it can be estimated according to the factor model proposed by Abadie et al. (2010)Total it $_{\text {K }}=$

\footnotetext{
5 The import and export data of Zhuhai free trade area are from Zhuhai Hengqin Free Trade Area Management
} Committee, while Zhuhai import and export data are from the statistical yearbook of prefecture level cities. 
$\delta_{t}+\theta_{t} Z_{i}+\gamma_{t} \mu_{i}+\varepsilon_{i t}$ 。 $\delta_{t}$ It is the time fixed effect which has the same influence on the import and export of all prefecture level cities; $Z_{i}$ Is the observable control variable; $\theta_{t}$ yes $1 \times r$ The parameter vector of dimension control variable; $\mu_{i}$ It is the region fixed effect that cannot be observed; $\gamma_{t}$ Is the period effect of the unobserved variable; $\varepsilon_{i t}$ It is the instantaneous impact produced by prefecture level cities, and its average value at the level of prefecture level cities is 0.It is assumed that the pilot free trade zone is set up in the region with $\mathrm{I}=1$, while no free trade zone is set up in the other $\mathrm{w}$ regions (region $\mathrm{I}=2, \mathrm{~W}+1$ )。 There is one $W \times 1$ Weight vector of $\operatorname{dimension} \omega=\left(\omega_{2}, \ldots \omega_{W+1}\right)$, make $_{w} \geq 0(\mathrm{w}=2, \ldots, \mathrm{W}+1)$, and $\omega_{2}+\cdots+\omega_{w+1}=1$ 。Every vector $\omega$ The eigenvalues of the two methods represent a combination of potential synthetic control

$$
\begin{gathered}
\sum_{w=2}^{W+1} \omega_{w} \text { Total }_{w t}=\delta_{t}+\theta_{t} \sum_{w=2}^{W+1} \omega_{w} Z_{w}+\gamma_{t} \sum_{w=2}^{W+1} \omega_{w} \mu_{w}+\sum_{w=2}^{W+1} \omega_{w} \varepsilon_{w t} \\
\text { Suppose there is a set of vectors }\left(\omega_{2}^{*}, \ldots, \omega_{W+1}^{*}\right) \text { Make: } \\
\sum_{w=2}^{W+1} \omega_{w}^{*} \text { Total }_{w 1}=\text { Total }_{11}, \ldots, \sum_{w=2}^{W+1} \omega_{w}^{*} \operatorname{Total}_{w T_{0}}=\text { Total }_{1 T_{0}} \text { and } \sum_{w=2}^{W+1} \omega_{w}^{*} Z_{w}=Z_{1} \\
\text { It can be proved that if } \sum_{t=1}^{T_{0}} \gamma_{t}^{\prime} \gamma_{t} \text { If they are nonsingular, they are: } \\
\text { Total }_{1 t}^{K}-\sum_{w=2}^{W+1} \omega_{w}^{*} \text { Total }_{w t}=\sum_{w=2}^{W+1} \omega_{w}^{*} \sum_{s=1}^{\mathrm{T}_{0}} \gamma_{\mathrm{t}}\left(\sum_{\mathrm{n}=1}^{\mathrm{T}_{0}} \gamma_{\mathrm{t}}^{\prime} \gamma_{\mathrm{n}}\right)^{-1} \gamma_{\mathrm{s}}^{\prime}\left(\varepsilon_{\mathrm{ks}}-\varepsilon_{1 \mathrm{~s}}\right)-\sum_{w=2}^{W+1} \omega_{w}^{*}\left(\varepsilon_{\mathrm{ks}}-\varepsilon_{1 \mathrm{~s}}\right)
\end{gathered}
$$

If the time range before the implementation of the policy is longer than that after the implementation of the policy, according to Abadie et al (2010), the mean value on the right side of equation (9) tends to be 0 . After the establishment of the pilot Free Trade Zone, the $\sum_{w=2}^{W+1} \omega_{w}^{*}$ Total $_{w t}$ as Total ${ }_{1 t}^{k}$. After the establishment of the Free Trade Zone, the estimated value of trade effect on import and export is as follows:

$$
\hat{\beta}_{1 \mathrm{t}}=\operatorname{Total}_{1 \mathrm{t}}-\sum_{\mathrm{w}=2}^{\mathrm{W}+1} \omega_{\mathrm{w}}^{*} \operatorname{Total}_{\mathrm{wt}}, \quad \mathrm{t} \in\left[\mathrm{T}_{0}+1, \ldots, \mathrm{T}\right]
$$

According to the above, we can estimate the trade effect of the establishment of the pilot Free Trade Zone on imports and exports by the same method.

2. Empirical analysis of the heterogeneity of each pilot free trade zone 
Table 9. weights of import and export control group areas in each composite control area

\begin{tabular}{|c|c|c|c|c|c|c|c|c|c|c|}
\hline & Tianjin & Shenyang & Dalian & Yingkou & Chongqing & Zhoushan & Fuzhou & Xiamen & $\begin{array}{l}\text { Zheng } \\
\text { zhou }\end{array}$ & Chengdu \\
\hline Dongguan & 0.535 & - & 0.035 & - & - & 0.035 & - & 0.013 & - & - \\
\hline Beijing & 0.066 & - & 0.083 & - & 0.055 & - & - & 0.058 & 0.005 & 0.042 \\
\hline Jinhua & 0.398 & - & - & 0.001 & 0.945 & - & - & - & 0.995 & 0.385 \\
\hline Dandong & - & 0.259 & - & 0.01 & - & - & - & - & - & - \\
\hline Huizhou & - & 0.124 & 0.013 & - & - & - & - & 0.444 & - & - \\
\hline Rizhao & - & 0.014 & - & 0.017 & - & - & - & 0.083 & - & 0.574 \\
\hline Jiangmen & - & 0.139 & - & - & - & - & - & - & - & - \\
\hline Hengshui & - & 0.109 & - & - & - & - & - & - & - & - \\
\hline Guiyang & - & 0.296 & - & - & - & - & - & - & - & - \\
\hline Yinchuan & - & 0.033 & - & - & - & - & - & - & - & - \\
\hline Changchun & - & 0.028 & - & - & - & - & 0.161 & - & - & - \\
\hline zhongshan & - & - & 0.228 & - & - & - & & - & - & - \\
\hline Suzhou & - & - & 0.041 & - & - & - & - & 0.004 & - & - \\
\hline Lanzhou & - & - & - & 0.625 & - & - & - & - & - & - \\
\hline Binzhou & - & - & - & 0.145 & - & - & - & - & - & - \\
\hline Shijiazhuang & - & - & - & 0.035 & - & - & 0.287 & - & - & - \\
\hline Dongying & - & - & - & - & - & 0.32 & - & - & - & - \\
\hline Urumqi & - & - & - & - & - & 0.403 & - & - & - & - \\
\hline Baoding & - & - & - & - & - & 0.167 & - & - & - & - \\
\hline Nanjing & - & - & - & - & - & - & 0.432 & - & - & - \\
\hline Nanchang & - & - & - & - & - & - & 0.12 & - & - & - \\
\hline Foshan & - & - & - & - & - & - & - & 0.399 & - & - \\
\hline \multirow[t]{2}{*}{ Haikou } & - & - & 0.6 & - & - & - & - & - & - & - \\
\hline & Kaifeng & Luoyang & Wuhan & Yichang & Xiangyang & Guangzhou & Luzhou & Zhuhai & Xi'an & Xianyang \\
\hline Beijing & - & - & - & - & - & 0.025 & - & 0.201 & - & - \\
\hline Karamay & 0.022 & - & - & - & 0.066 & - & - & - & - & 0.252 \\
\hline Nanchong & 0.126 & - & - & - & - & - & - & - & - & \\
\hline Songyuan & 0.268 & - & - & - & - & - & - & - & - & 0.046 \\
\hline Cangzhou & 0.3 & - & - & - & - & - & - & - & - & - \\
\hline Zunyi & 0.027 & 0.295 & - & - & - & - & - & - & - & - \\
\hline Sanya & - & 0.144 & - & 0.085 & 0.034 & - & - & - & - & - \\
\hline Luliang & - & 0.151 & - & 0.001 & 0.069 & - & - & - & - & - \\
\hline Jinzhong & - & 0.04 & - & - & - & - & - & - & - & 0.183 \\
\hline Binzhou & - & 0.019 & - & - & - & - & - & - & & - \\
\hline Mudanjiang & - & 0.017 & 0.091 & - & - & - & - & - & 0.114 & - \\
\hline qinghuangdao & - & 0.228 & & - & - & - & - & - & - & - \\
\hline Tangshan & - & - & 0.199 & 0.001 & - & - & - & - & - & - \\
\hline Ningbo & - & - & 0.122 & & - & - & - & - & - & - \\
\hline Chongzuo & - & - & 0.39 & 0.013 & - & - & - & - & 0.563 & - \\
\hline Yantai & - & - & 0.033 & & - & - & - & - & 0.004 & - \\
\hline Shijiazhuang & - & - & 0.164 & 0.001 & - & - & - & - & - & - \\
\hline Sanming & - & - & - & 0.029 & - & - & - & - & - & - \\
\hline Shangrao & - & - & - & 0.003 & - & - & - & - & - & - \\
\hline Datong & - & - & - & 0.025 & 0.073 & - & - & - & - & - \\
\hline Daqing & - & - & - & 0.012 & - & - & - & - & - & - \\
\hline Taiyuan & - & - & - & 0.003 & - & - & - & 0.205 & - & - \\
\hline Yueyang & - & - & - & 0.21 & - & - & - & - & - & - \\
\hline Xinyu & - & - & - & 0.124 & - & - & - & - & - & - \\
\hline Lanzhou & - & - & - & - & 0.122 & - & - & - & - & 0.015 \\
\hline Xiaogan & - & - & - & - & 0.127 & - & - & - & - & \\
\hline Dongguan & - & - & - & - & - & 0.127 & - & - & 0.003 & - \\
\hline Foshan & - & - & - & - & - & 0.694 & - & - & 0.05 & - \\
\hline Suzhou & - & - & - & - & - & 0.154 & - & - & - & - \\
\hline Kunming & - & - & - & - & - & - & - & 0.336 & - & - \\
\hline Hangzhou & - & - & - & - & - & - & - & 0.212 & - & - \\
\hline Jinhua & - & - & - & - & - & - & - & - & 0.266 & - \\
\hline Sanmenxia & - & - & - & - & - & - & - & - & - & 0.145 \\
\hline huaihua & - & - & - & - & - & - & 0.223 & - & - & 0.176 \\
\hline lijiang & - & - & - & - & - & - & 0.165 & - & - & - \\
\hline Zhangjiajie & - & - & - & - & - & - & 0.246 & - & - & - \\
\hline
\end{tabular}


Note: the first column lists the name of the target area, and the control group area is in the first column on the left. Taking Tianjin as an example, Tianjin is composed of 53.5\% Dongguan, 6.6\% Beijing and $39.8 \%$ Jinhua. The total weight of each column is 1 .

According to the above, the pilot free trade zones established in 2017 and before are distributed in 22 prefecture level cities. In view of the different implementation time points of domestic free trade laboratories and the specific development direction of the pilot free trade zone planning, the research in this part no longer adopts the method of mixed research on the free trade

trade zones, but analyzes each pilot free trade zone separately. The impact of the pilot Free Trade Zone on trade is measured by the difference between the import and export of each target area and the composite control area.The "counterfactual" objects of 22 cities where the pilot free trade zones are located are constructed by the method of composite control, and the effects of the free trade zones are analyzed. This paper uses the data of control group of prefecture level cities from 2004 to 2012 to fit the "counterfactual" objects of Shanghai Free Trade Zone, the data of control group from 2004 to 2014 fit the "counterfactual" objects of Tianjin, Guangdong and Fujian free trade zones, and the data of 2004-2016 fit the "counterfactual" objects of the other seven pilot free trade zones. Taking Shanghai as an example, Shanghai pilot free trade zone was established in 2013. The import and export, import and export from 2004 to 2012 were used as predictive control variables to fit the composite control object of Shanghai. The trade effect of Shanghai's implementation of free trade zone policy is reflected by the difference of import and export, import and export between Shanghai and its composite control area after 2013.The optimal weight of the composite control group corresponding to all target areas is calculated by estimating the corresponding synth package. The selection standard of the optimal weight is to minimize the mean square error of import and export of the two in the period before the implementation of the policy 。

According to the above composite weight, the import and export data of 22 regions of 11 free trade zones can be synthesized by using the synthetic control method, and a total of 22 maps are obtained, as shown in Appendix 1.The solid line represents the actual growth path of the import and export of the respective pilot Trade Zone, and the dotted line represents the growth path of the composite control object. By comparing the dotted line with the solid line, the following points are found:

(1) On the left side of the vertical line, it represents the fitting effect of the control group to the experimental group. Most of the cities where the pilot free trade zones are located can be well fitted. However, Shanghai, Shenzhen, Chongqing and Zhengzhou can not be well fitted. The synthetic control method requires that the weights of the cities in the control group are all positive, and the sum is 1 . The individual eigenvectors of the experimental groups of the four cities are far away from the combination of the eigenvectors of the control groups. Because Shanghai and Shenzhen are the most developed cities in China, the volume of import and export trade is much larger than most other cities. When choosing the control object, Shanghai and Shenzhen only choose the closest city Beijing, which is given a weight of 1.Chongqing and Zhengzhou are the cities with rapid development in China in recent years. From the comparison between the dotted line and the solid line, we can find that the solid line of Chongqing and Zhengzhou is lower than the dotted line in the early stage, and the solid line is higher than the dotted line in the later stage.

(2) On the right side of the vertical line, the deviation of solid line and dotted line represents the effect of policy implementation. According to Appendix $1^{6}$, the policy effect mainly shows three situations. First, the cities are Tianjin and Zhuhai, and the total import and export volume after the implementation of the policy is lower than the control combined data; second, the policy implementation does not show obvious effect, and the cities of Chongqing, Zhoushan and Yichang show no significant difference before and after the implementation of the policy; third, the policy implementation shows obvious effect, It includes 17 other cities except Tianjin, Zhuhai, Chongqing, Zhoushan and Yichang. The typical representative cities include Luzhou, Xianyang and Xiamen. After the implementation of the policy, the total import and export volume is significantly higher than that of the control combined data. The possible reasons for the three effects are as follows: first, while the local government implemented the free trade zone policy, other major events occurred, which had a significant impact on import and export. For example, Tianjin implemented the free trade zone policy in 2015, and the explosion occurred in Tianjin port in the same year, which had a great impact on import and export; second, the import and export data of prefecture level cities failed to reflect the import and export data of the free trade zone very well, For example,

${ }^{6}$ Due to space limitation, not all cities are include in the Appendix. If you are interested, please ask the author for them. 
the growth rate of import and export announced by the Management Committee of Zhuhai Hengqin Free Trade Zone reached $66.33 \%$, but the growth rate of Zhuhai's import and export was slower than that of the whole country. Third, the specific tasks undertaken by various FTZs are different. Some FTZs are more focused on the field of financial services trade, and their role in promoting the import and export of goods is not particularly obvious. For example, Zhoushan City mainly undertakes the experimental tasks of bulk oil storage, financial services and high-tech development, which leads to a significant increase in imports, while the export growth is slower than that of other cities in the country. As a result, the free trade zone policy has no obvious effect on import and export.

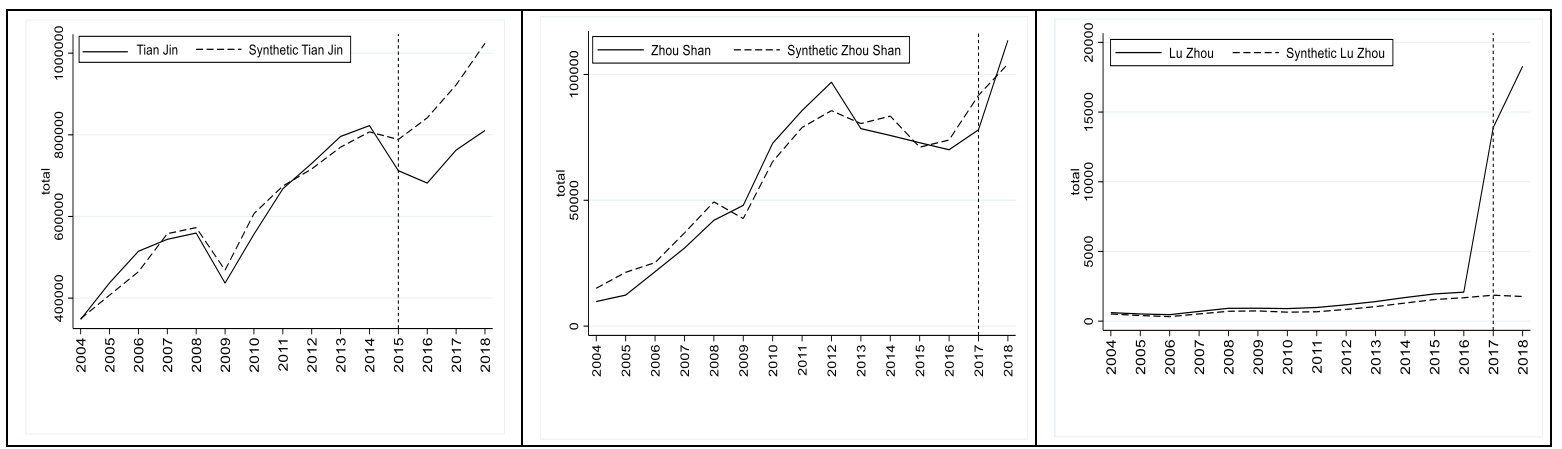

Figure 2. total trade of target and composite controlled areas

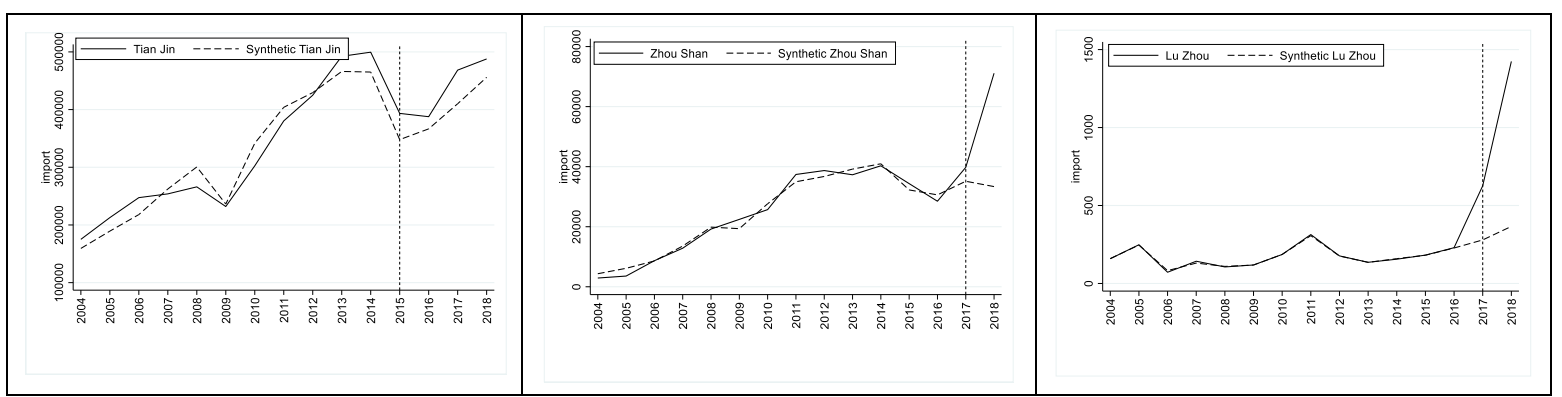

Figure 3. import of target and composite controlled areas

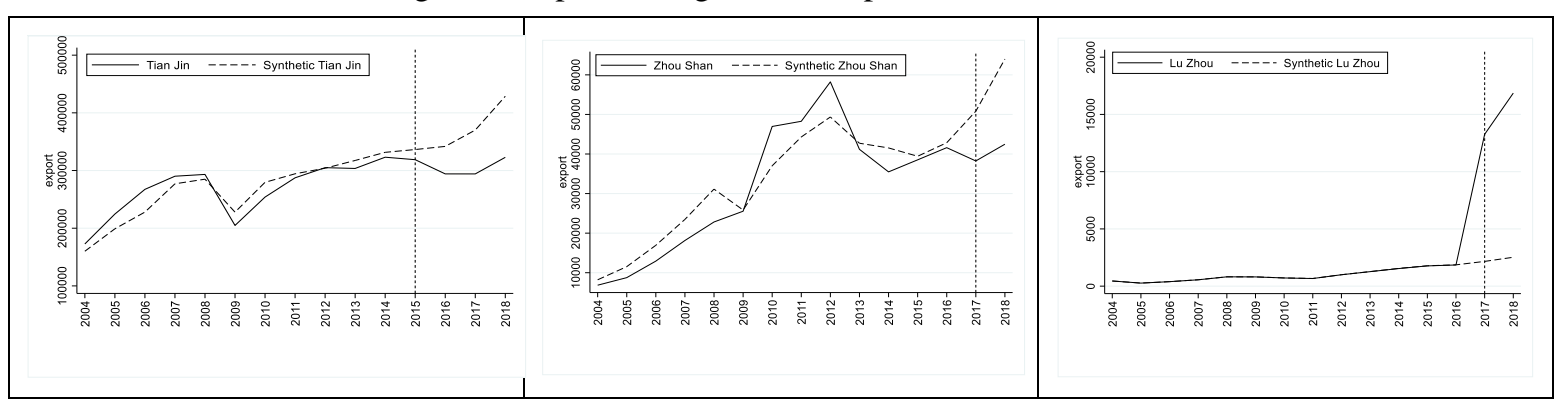

Figure 4. export of target area and composite control areas

(3) In order to better investigate the trade effect of the free trade zone, this paper uses the synthetic control method to analyze the import and export. The special items of Tianjin, Zhoushan and Luzhou are listed in Figure 2 and figure 3. See Appendix 2 and Appendix 3 for details. Firstly, from the perspective of export, the export trade effect of Tianjin, Shenyang, Dalian, Yingkou, Chongqing, Zhoushan and Xiamen is negative, that is, the free trade zone policy fails to promote the growth of local export trade. The possible reasons for this phenomenon are as follows: first, the total export volume of prefecture level cities is large, and the export within the pilot free trade zone is increasing, and the prefecture level cities can not well reflect the trade effect of the free trade zone policy; second, the specific tasks undertaken by the pilot free trade zone have little impact on the export and fail to produce obvious export promotion effect; third, these cities are all eastern cities except Chongqing, Eastern cities may be more affected by Sino-US trade frictions, resulting in slower export growth. In addition to the above-mentioned seven free trade areas, the other 15 free trade areas show a promoting effect on export. On the whole, the pilot free trade zones promote the growth of export trade. Secondly, from the perspective of import, seven prefecture level cities such as Shenyang, Yingkou, Fuzhou, Luoyang, Wuhan, Yichang and Zhuhai showed negative correlation, while the other 17 prefecture level cities showed positive 
correlation. On the whole, the free trade zone can promote the import. Thirdly, considering the relationship between the import and export of the free trade zone, in the central and western regions, the promotion effect of export is obviously greater than that of import, while in the eastern region, it is just the opposite. The possible reason is that the eastern region is more developed than the western region. After the implementation of the policy, the demand for overseas products is greater and the promotion of import is greater. However, the economy of the central and western regions is less developed than that of the eastern regions. After the implementation of the policy, more foreign capital and local labor force are used to produce products for export, which has a greater role in promoting export. For the size of specific trade effects, see Table 10.

Table 10. trade effect after the implementation of pilot Free Trade Zone

\begin{tabular}{|c|c|c|c|c|c|c|c|}
\hline \multirow{2}{*}{$\begin{array}{l}\text { Free Trade } \\
\text { Zone }\end{array}$} & \multicolumn{3}{|c|}{ Trade effect } & \multirow{2}{*}{$\begin{array}{l}\text { Free Trade } \\
\text { Zone }\end{array}$} & \multicolumn{3}{|c|}{ Trade effect } \\
\hline & Total & Import & Export & & Total & Import & Export \\
\hline Tianjin & $-152,320$ & 39,197 & $-61,773$ & Wuhan & 13,665 & $-16,588$ & 15,315 \\
\hline Shenyang & 12,766 & $-2,104$ & -363 & Yichang & 248 & -875 & 2,664 \\
\hline Dalian & 27,511 & 56,303 & $-33,749$ & Xiangyang & 5,733 & 383 & 4,805 \\
\hline Yingkou & 5,330 & -836 & $-2,221$ & Chengdu & 153,415 & 57,964 & 62,877 \\
\hline Chongqing & 12,695 & 75,499 & $-61,698$ & Luzhou & 14,271 & 703 & 12,718 \\
\hline Zhoushan & $-2,135$ & 21,187 & $-17,050$ & Xi'an & 91,824 & 10,288 & 77,247 \\
\hline Fuzhou & 13,825 & $-2,615$ & 7,958 & Xianyang & 1,869 & 1,017 & 928 \\
\hline Xiamen & 77,221 & 66,528 & $-44,756$ & Guangzhou & 99,687 & 6,926 & 36,696 \\
\hline Zhengzhou & 35,727 & 41,571 & 31,141 & Zhuhai & $-80,527$ & $-96,242$ & 12,728 \\
\hline Kaifeng & 1,668 & 120 & 1,789 & Shenzhen & 600,000 & 71,941 & 375,000 \\
\hline Luoyang & 427 & $-1,781$ & 1,472 & Shanghai & 633,333 & 281,451 & 100,000 \\
\hline
\end{tabular}

Note: the trade effect is measured by subtracting the control portfolio from the actual average value after the implementation of the policy.Taking Tianjin's import and export as an example, the trade effect is obtained by subtracting the average value of Tianjin's actual import and export from 2015 to 2018.

\section{Conclusions and Policy implications}

\section{(1) Research conclusion}

This paper first gives a brief introduction to the development of free trade zones, and summarizes the functional orientation, main tasks and scale of the 18 pilot free trade zones established in China. Based on the provincial panel data, this paper makes a descriptive analysis on the import and export situation of the provinces where the free trade zone is located. Based on the panel data of prefecture level cities from 2004 to 2018, this paper analyzes the trade effect of the free trade zone by using the method of phased did, and analyzes the heterogeneity of the free trade zone by using the method of composite control. The following conclusions are drawn: first, in statistics, the pilot free trade zone has an obvious promoting effect on import and export, while the promotion effect on import is not obvious; second, the pilot free trade zone plays an important role in promoting import, export and export,The pilot free trade zone mainly promotes the growth of import and export trade through institutional innovation, trade facilitation and investment facilitation; thirdly, the trade promotion of the pilot free trade zone to the central and western regions is more obvious, but it is not obvious in the eastern region, This may be related to the main task of the free trade zone undertaken by the eastern region and the more developed economy of prefecture level cities in the eastern region, which is more affected by the external international trade environment. Fourthly, in the analysis of each free trade zone, Tianjin and Zhuhai show a negative correlation, while other cities show a significant positive correlation. Excluding Shanghai, Shenzhen and Chongqing with poor fitting effect, compared with imports, the FTZ has a greater role in promoting exports.

\section{(2) Policy implications}

The pilot free trade zone is an important exploration for China to further deepen the reform and opening up, and the requirement for it is that most of the systems can be popularized and replicated in the whole country. The opening of the free trade zone has a significant role in promoting China's import and export, but also has a 
certain impact on China's own economic development. Therefore, the following work should be done well in perfecting the system construction of the free trade zone and promoting and reproducing in the whole country. First, to handle the relationship between domestic pilot free trade zones and international bilateral free trade zones, we should not only make the international pilot free trade zones as a supplement to the free trade zones and promote China's reform and development; on the other hand, we should prevent the excessive policy opening of domestic pilot free trade zones, which will have a significant impact on domestic enterprises and affect the established bilateral free trade agreements. Second, in terms of statistical analysis, it is found that the central and Western pilot free trade zone has a greater trade promotion effect. On the premise of protecting the industries in the central and western regions from being impacted, we can consider accelerating the promotion and replication of the pilot free trade zone policy in the central and Western regions, so as to promote the coordinated development of the eastern and western regions of China's economy. Third, to prevent excessive innovation of the system, investment facilitation and trade facilitation should be established on the basis of laws and repeated arguments. For example, the "negative list" system can not be reduced blindly, but should comprehensively consider the applicability of the law and the impact on the existing domestic industries to prevent the risk of capital liquidity.

\section{References}

Abadie, A., \& Javier, G. (2003). The economic costs of conflict: A case study of the Basque Country. [J] American economic review, 93(1), 113-132. https://doi.org/10.1257/000282803321455188

Abadie, A., \&Alexis, J. (2010). Synthetic control methods for comparative case studies: Estimating the effect of California's tobacco control program [J]. Journal of the American statistical Association, 105(490), 493-505. https://doi.org/10.1198/jasa.2009.ap08746

Abadie \& Alberto. (2005). Semiparametric difference-in-differences estimators [J]. The Review of Economic Studies, 72(1), 1-19. https://doi.org/10.1111/0034-6527.00321

Bi, Y. J., Tang, H. Y., \& Yin, D. S. (2014). Constraints and Countermeasures of Shanghai free trade zone transformation $[\mathrm{J}]$. Economic review, 8, 8-12

Chen, A. Z., \& Liu, Z. B. (2014). Free Trade Zone: the second quarter of China's open economy [J]. Academic monthly, 1, 20-28.

Chen, Q., \& Liu, W. (2014). Analysis on the motivation and economic effect of establishing China (Shanghai) pilot free trade zone [J]. Scientific development, 2014(2), 43-50

Chen, S. H., Tao, L. Y., \& Huang, J. (2014). A study on the development of service trade under the background of Shanghai Free Trade Zone. Fudan University Press, first edition, May.

Expert group of Shanghai University of international business and economics. China (Shanghai) free trade zone and international economic cooperation $[\mathrm{M}]$. Shanghai University of Finance and Economics Press, December 2013, First edition.

Han, R. D., \& Bo, B. (2019). Research on the effect of Free Trade Zone on capital flow - Based on the perspective of quasi natural experiment [J]. International Financial Studies, 7, 11-19.

Li. G. H., \& Wang, R. (2017). The achievements of FTZ construction in China and the direction of future development[J]. International Trade, 7, 4-6.

Liu, B. L., \& Wang. (2018). Research on the effect of Free Trade Zone on Regional Innovation Capability: evidence from quasi experiment of Shanghai pilot free trade zone [J]. Economic and management research, 9, 65-74.

Liu, B. L., \& Lv, C. (2018). the influence of regional trade control on the international free trade zone: Based on the comparative analysis of the regional trade. Control, 3, 51-56.

Sheng, B. (2017). Evaluation and Prospect of China pilot free trade zone [J]. International trade, 6, 7-13.

Tan, N., Zhou, X. B., \& Lin, J. H. (2015). Research on the economic growth effect of Shanghai Free Trade Zone: a counterfactual analysis method based on Panel Data [J]. international trade issues, 10, 14-24.

Wang, L. H., \& Liu, Z. H. (2017). Research on the effect of Shanghai Free Trade Zone on regional economy [J]. International trade issues, 2, 3-15.

Wang, L. L. (2019). Trade Effects of China (Shanghai) Free Trade Zone [J]. New Horizons, 6, 72-79, 85.

$\mathrm{Wu}, \mathrm{X} . \mathrm{T}$. (2015). Review of theoretical framework of free trade zone at home and abroad [J]. Modern trade 
industry, 10, 65-67.

Xiang, H. J., \& He, K. (2016). The impact of free trade zone and capital flow: a natural experimental study on Shanghai [J]. International trade issues, 8, 3-15

Yang, X. D. (2014). Preliminary study on the relationship between economic and political effects of China (Shanghai) pilot free trade zone [J]. Journal of Shanghai University of Finance and economics, 6, 97-104.

Ye, X. Q. (2018). A study on the economic effects of free economic zone in China [D]. East China Normal University.

Yin. H., \& Gao, W. H. (2017). Does the free trade zone produce an "institutional dividend" effect? Evidence from the Shanghai Free Trade Zone [J]. Financial Research, 2, 48-59.

Zhang, Y. W. (2014). Experiment of free trade zone and construction of open economic system [J]. Academic monthly, 4, 11-19. 


\section{Appendix:}

\section{Appendix 1}

Total trade effect

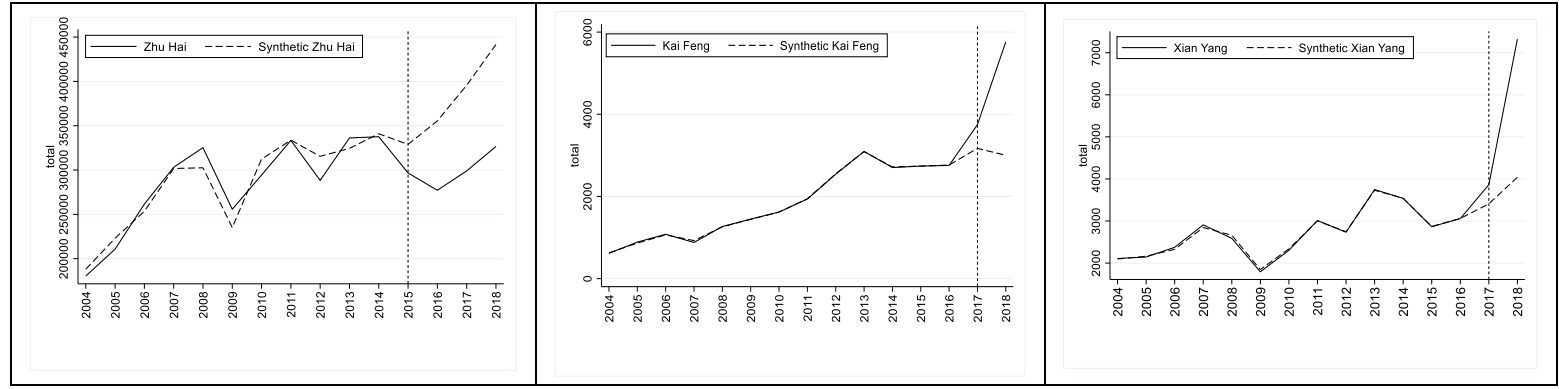

\section{Appendix 2}

Import trade effect

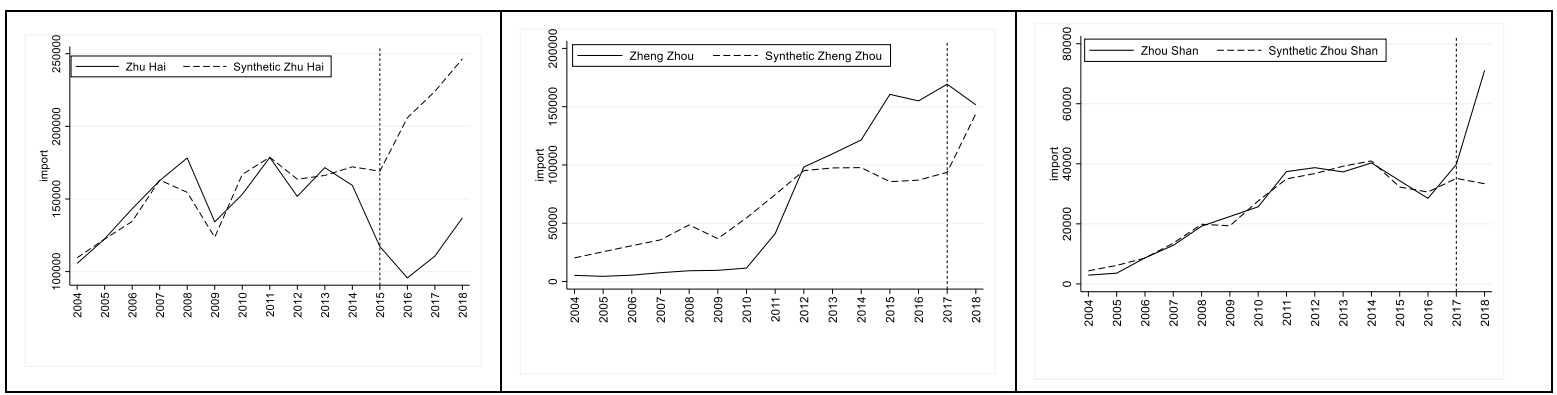

Appendix 3

Export trade effect

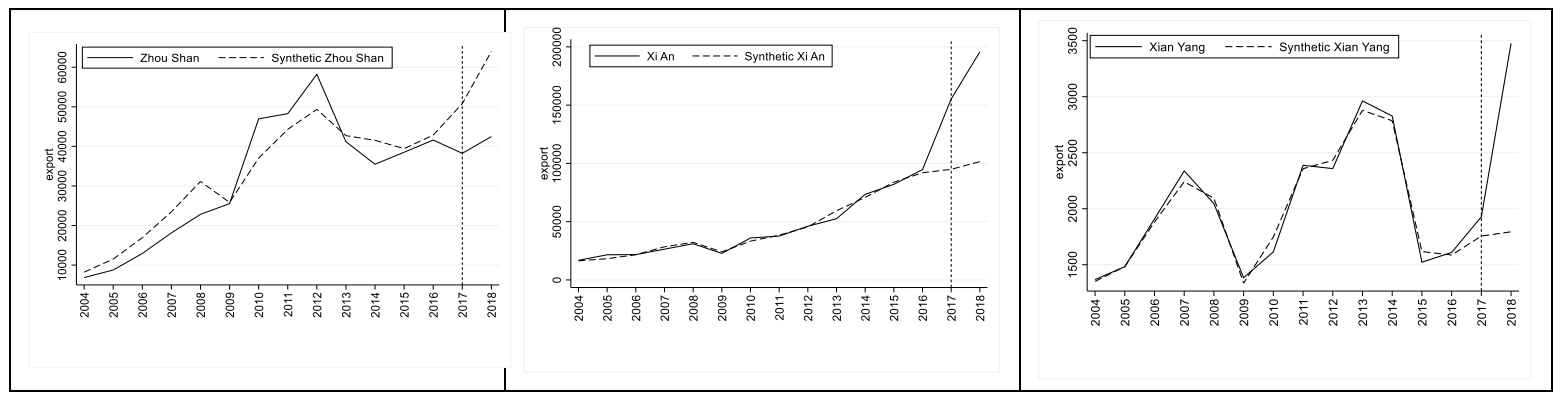

\section{Copyrights}

Copyright for this article is retained by the author(s), with first publication rights granted to the journal.

This is an open-access article distributed under the terms and conditions of the Creative Commons Attribution license (http://creativecommons.org/licenses/by/4.0/). 